\title{
相当外気温に関する実験的一考察
}

正会員 ○浦野良美* 同古 野 強**

はじめに 冷房負荷算定の際日射の影響はこれを戸 外気温に合めて仮想の戸外気温を考元相当外気温として 実用されている。非定常熱負荷計算において熱回路網に 依る電気的な解析を行なえるが、外気温と日射熱量とを 分けて入力とするより相当外気温を仮定して入力とする 方が簡便なのはもちろんである。ASHVEの Guide は 相当外気温を熱容量の大きなコンクリート壁等に用いる 時は振幅減少率とタイムラグの表を与えて非定常熱移動 なる補正を行なっており $\left[{ }_{\Delta} t_{e}=\left(t_{e m}-t_{r}\right)+f\left(t^{\prime}{ }_{e}-t_{e m}\right)\right]$, この補正法を熱回路法に依る解と比較検討したいと考え た。本報告はこの予備的な段階であるが、相当外気温を 求めるための熱常数 (外壁側熱伝達率 $\alpha_{0}$, 日射吸収率 $a$ ) のデーターが米国 (Guide) のものであり、日射熱量を 対象とした実験は過渡的現象として把握しなければなら ない等の理由で未だ允分な実験がなされていないので、 日射熱量がコンクリート壁の熱移動に与える状況を知る ために第 1 図の実験装置を作製し、相当外気温に対して の考察を一部行なったものである。

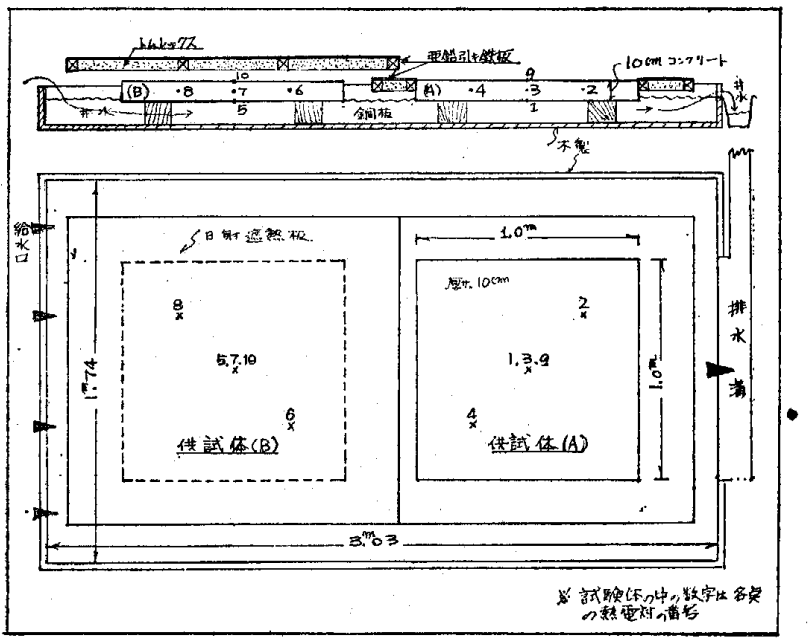

第 1 図 実 験 装 置

\section{§1 供試体および実験法概要}

場所 : 福岡市九大建築学教室屋上.

測定期日：1962年 8 月 4 日より11日まで、連続测定 共試体 : コンクリート、 $1 \mathrm{~m} \times 1 \mathrm{~m} \times 0.1 \mathrm{~m}$ ( 2 ケ)。実測 飞依り $\lambda=1.26, \rho=2300, C_{p}=0.2, \lambda / C_{p} \bullet \rho=0.00274$ なお $a=0.7$ と仮定した。

測定器具：12打点温度記録計。エプリ日射計。温度、 風速、風向、雲量は10分每に観測。

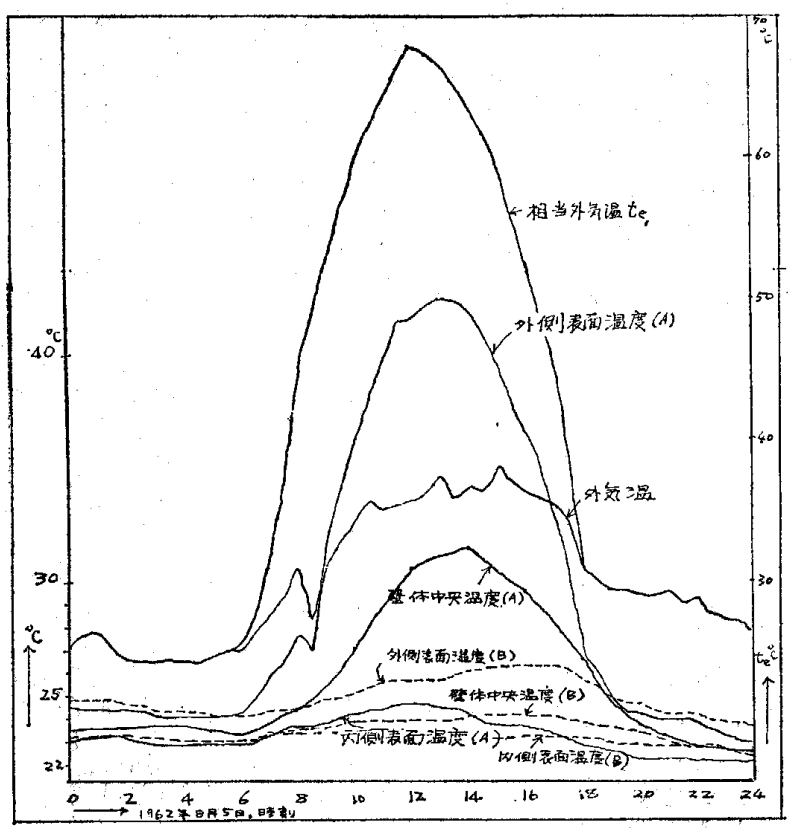

第 2 図温度分布図

$\S 2$ 実験結果亡考察 無風 $(0.5 \mathrm{~m} / \mathrm{sec})$ 、快晴の 8 月 5 日の供試体 (A) と (B) の時刻別温度分布図を第 2 図に示す。供試体（A）は日射の影響を受けるが供試体 （B）は影響をほとんど受けず、日射以外の条件は同一 とみなされる。 $t_{A}, t_{B}$ をそれぞれ外表面温度とすれぱ

供試体 (A) の取得熱量 $q(\mathrm{~A})=a \cdot I_{t}+\alpha_{0}\left(t_{0}-t_{A}\right)$

"(B) " $q(\mathrm{~B})=\alpha_{0}\left(t_{0}-t_{B}\right)+q_{e}$ ( $q_{e} \fallingdotseq 0$ とした $)$

日射に依る取得熱量增加分 $\Delta q$

$$
\Delta q=q_{(\mathrm{A})}-q_{(\mathrm{B})}=a \cdot I_{t}-\alpha_{0}\left(t_{A}-t_{B}\right)
$$

$I_{t}, t_{A}, t_{B}$ の実測值から $a ， \alpha_{0}$ を仮定すれば時刻別の $\Delta q$ を求める事が出来る。例えばピーク值で (12時)、 $a=0.7, \alpha_{0}=20$ を仮定すると、 $\Delta q=0.7 \times 833.3-20$ $(41.5-25.8)=583.3-314.0=269.3 \mathrm{kcal} / \mathrm{m}^{2} \cdot \mathrm{h}$ 。乙の例 て、、日射吸収量 $a \cdot I_{t}$ に対して放散熱伝達量か $50 \%$ を越 しており、また現在数学解と実験值の比較を行なってい るが位相ズレは良く一致するも振幅は非常な差が出てい

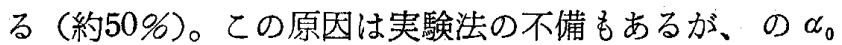
值を 20 とするのは大に過ぎるのはないか、風速と表面の 粗滑に依り求めた $\alpha$ の值を、日射に依り暖められた外壁 からの低温輻射を考慮に入れて再検討する必要があると 思われる。

\footnotetext{
* 九大助教授 工博 $* *$ 高砂熱学 $\mathrm{K} . \mathrm{K}$.
} 